\title{
HOW TO MANAGE BUSINESS ETHICS EFFECTIVELY?
}

\author{
by Tran Kiem Viet Thang ${ }^{l}$
}

\begin{abstract}
The main purpose of this paper is exploring ways to manage business ethics effectively. To achieve this, first of all, the paper reviews the concepts and importance of business ethics together with its components, such as corporate ethics codes and corporate social responsibility (CSR). Next, five ways to manage business ethics efficiently are revealed. Based on these suggested ways, the paper recommends four practical actions for managers to have good management skills in this field. These recommendations are setting up an effective corporate ethics code, acting and behaving ethically in any circumstances, setting up rules and regulations, and advancing CSR in a very wise way. The paper concludes with two issues for future researchers: whether corporations need a business ethics manager/ specialist, and how companies motivate their employees to act ethically.
\end{abstract}

Keywords: business ethics, corporate ethics code, corporate social responsibility.

\section{INTRODUCTION}

Business ethics was such a new concept that not many people were concerned about it. Anyway, things have changed over the time, and now business ethics plays a very important role in doing business (Mitchell, 2003). The need to manage business ethics becomes essential. In addition, not all cases related to business ethics management are successful (Cooper \& Nakabayashi, 2010; Pedersen, 2006). Therefore, how to manage it effectively is very important to managers.

This research paper helps to answer the question above. Before addressing ways to help business people manage business ethics successfully, the research describes the literature framework and importance of business ethics together with its core components such as corporate ethics codes and corporate social responsibility (CSR).

Next, five ways to manage business ethics effectively are listed: building an effective corporate ethics code (Mitchell, 2003), improving codes of ethics to change behavior (Buckhoff \& Wilson, 2008; Lere \& Gaumnitz, 2007), protecting against deception (Adler, 2007), making an ethical program work (Grace \& Haupert, 2006), and advancing CSR (Porter \& Kramer, 2006).

The remaining part of the research reveals four recommendations and two questions for future researchers. A final part summarizes all of the above.

\section{BRIEF HISTORY}

Garone (1994) stated that "It is not difficult to remember when the concept of 'business ethics' was a novelty to most people. It was taken largely for granted by business executives and it attracted little public attention" (p. 9). In addition, according to Mitchell (2003), there were many CEOs who focused on taking care of their own individual importance rather than their corporation's functioning and profit. Apparently, these presented above 
show us that business people ignored or were not fully aware of the significance of business ethics.

However, things have changed over the time, and ethics has recently played an important role in doing business. Moreover, "corporations of all sizes, especially multinationals, are more attuned to the bottom-line value of being a good corporate citizen and playing by the rules, and individual business people are seeking to do 'what is right' rather than 'anything to close the deal"' (p. 2).

Although business ethics is already considered to be significant these days and corporations' ethical standards and morals have been set to manage it, not all the cases are successful. For example, the scandal of melamine in milk in China revealed the unethical aspects in doing business (DeLaurentis, 2009); the Chinese corruption is so popular all over the world that many foreign companies with operations in China have to find ways to deal with this phenomenon (Pedersen, 2006); additionally, the U.S. and Japanese life insurance markets faced up to serious ethical turmoil "in the marketing and management of insurance products, resulting in an erosion of public trust in the industry" (Cooper \& Nakabayashi, 2010, p. 64). In 2007, seventeen Vietnamese soy sauce producing companies were found guilty for violating food safety regulations by surpassing the permitted level of 3-MCPD, a cancer causing toxin. This serious scandal mostly destroyed the Vietnamese industry. From the unsuccessful cases presented above, the significance to know how to manage business ethics effectively is really necessary.

\section{LITERATURE REVIEW}

Business ethics defines how a company integrates its core values - such as honesty, trust, respect and fairness - into its policies, practices and decision-making. Business ethics also involves a company's compliance with legal standards and adherence to internal rules and regulations. As recently as decade ago, business ethics consisted primarily of compliance-based, legally-driven codes and training that outlined in detail what employees could or could not do in regard to areas such as conflict of interest or improper use of company assets. (Mitchell, 2003, p. 9)

Business ethics plays a very significant role in the business world. Epstein (2007) said that ethics "contributed to ever-escalating standards for corporate performance" (p. 217), so "more and more corporations see business ethics as a bottom-line issue - not an optional one of morality" (Mitchell, 2003, p. 2).

Let us move on to the code of ethics that is included in the definition of business ethics. Schwartz (2001) defined codes of ethics as "tools that are commonly used as one of the efforts to encourage ethical behavior, and there may be a great deal of room for improvement of existing codes" (as cited in Lere \& Gaumnitz, 2007, p. 7).

Apparently, without a specific tool to evaluate and motivate ethical behavior, corporations find themselves hard to let their staffs and employees follow the right, and the code of ethics helps them do that. When business people come up with any new circumstances that they have to make a decision but do not know how to do it, their company's code of ethics lightens up their mind. Thanks to the code of ethics, the staffs and employees can overcome the pressure of perceiving what they should do to follow the ethical standards and keeping off the unethical ones. Generally, the code of ethics is like a basis for companies to formulate their rules or regulations to orient themselves and their personnel. 
Another aspect of business ethics is corporate social responsibility (CSR) which is considered to be very important to build a company's reputation. CSR is a concept whereby companies integrate social and environmental concerns in their business operations and in their interaction with their stakeholders on a voluntary basis. Furthermore, "major corporations now wield more economic and political power than the governments under which they operate. In response, public pressure has increased for business to take on more social responsibility and operate according to higher ethical standards." (Mitchell, 2003, p.10).

This matter is considered to be a fair one because this is a two-way benefit: the societies create markets for corporations to trade their goods and services to earn profit, so in exchange, the companies have to do something beneficial for their societies. We cannot say it is a must for companies to do that, but they themselves have to be aware of CSR as a fair and good tendency to stick with.

\section{WAYS TO MANAGE BUSINESS ETHICS EFFECTIVELY}

First, building an effective corporate ethics code must be taken into consideration because not many companies have a written code of ethics although they have known about its significance. For instance, more than seventy percent of Australian and Japanese companies do not have a written code of conducts and ethics. However, in order to compete effectively, global companies must have and ensure that their ethics codes are culturally coherent to all employees. How can companies do this? Mitchell (2003) showed us that:

A corporate ethics code needs to be more than the rules of the road; it should include a statement of the company's core value. Code of conduct must provide clear direction about ethical behavior when the temptation to behave unethically is strongest. In a nutshell, the code should be:

- Easy to read

- Practical and relevant for each business or geographic market

- Sufficient but not excessive in detail

- Well written and accessible in tone (pp. 88-95)

For example, the code of ethics of the Verizon, a global leader in delivering innovative communications, information, and entertainment, is a lengthy document containing four short core values. They are integrity, respect, performance excellence, and accountability. The code provides specific rules and guidelines for every staff to know how to deal with workplace violence, alcohol use, harassment, and sabotage, how to avoid conflicts of interest, and how to safeguard company information.

Second, we can manage business ethics effectively by improving codes of ethics to change behavior. In detail, when we talk about changing behavior, we mention about changing perception, which "is formally described as changing the decision maker's beliefs (subjective probability distribution) as to whether an action is ethical". In general, the purpose of improving ethics codes to change behavior "can be achieved by careful (1) selection of code content and (2) design of enforcement mechanisms" (Lere \& Gaumnitz, 2007, pp. 7-12). Buckhoff and Wilson (2008) added that "the costs of dishonesty must exceed the benefits derived from dishonest behavior, so people will think twice before doing it" (p. 55).

Why corporations should have an enforcement mechanism or penalty? First, human beings are much diversified. We have many different kinds of people, including good and bad ones. Second, 
different kinds of people have different behaviors when faced with a particular issue. For example, in a travel agent, a tour guide can perceive that he deserves to receive tips from his customer because he has taken good care of the customer. On the contrary, the agent's board of management can perceive this differently that taking good care of customers is the tour guide's responsibility and vocational ethics, and of course he has to follow that. Here the problem appears, or we can say, this makes the related people confused.

Therefore, if the agent's board of management wants every tour guide not to receive any tips from customers, they have to set regulations to let the tour guides know that. This is a must, but not enough. Together with the regulations, the management board has to impose a penalty on their tour guides who receive tips. The penalties can be eliminating ten percent of monthly wage, three days off, or five percent of yearly bonus. Such kinds of penalty can let all tour guides think more seriously and carefully before receiving any tips or presents from their customers. In reality, the Hoan My Saigon Premier, a high-grade private hospital in Vietnam, follows this rule very well. It always provides good services although no one in this hospital dares to receive any tips from the patients unless he will be fired immediately. Thanks to this strict policy of the hospital, the patients feel very comfortable and totally trust that their doctors and nurses will take special care of them without any other demand. In general, we can be aware that business people will be discouraged to do something violating ethical principles thanks to thinking of penalties they would suffer.

Third, managing business ethics effectively can also be achieved by protecting against deception (Alder, 2007). Nowadays, we are living and working in an informative technology period of time, so we know for sure that information plays a very important role in doing business, especially making decisions. However, wrong information can be approached by business people because of deception, such as telling lies. Unfortunately, "one of the enduring truths about human beings is that we lie - frequently and often quite casual. Lying is a central aspect of human behavior". There is a fact that "according to the most conservative estimates of human resource managers, $25 \%$ of all résumés contain significant lies" (p. 69).

Especially, lying is extremely pervasive in negotiation process. Although we do not have any perfect tool to protect ourselves completely from this phenomenon, we "can greatly minimize the risk of lies in bargaining through a series of steps designed either to expose lies and liars before negotiations begin or to provide protection from lies". For example, before negotiations begin, "preparation is particularly critical when facing opponents for the first time and the stakes are high," and this preparation can be "researching the other side's character and bona fides, and participating scenarios that might play out in the negotiation". How about during the negotiation process? Adler (2007) advised us to "ask questions in different ways, take notes during negotiations, and trust but verify" to protect ourselves against deception (pp. 71-73).

Next, let us move on to the fourth way to manage business ethics effectively. That is, making our ethical program works. There is a framework called ESD that "Encourages everyone to work ethically, Supports those inclined to work ethically, and Deters those who may be tempted to veer from the path of ethical behavior". Three conditions are needed to run this program. First of all, a risk profile needs to be set up. Risk profile is "developed by 
public accountants, internal auditors, riskmanagement and legal staff, and perhaps outside help from consultants and errorand-omissions carriers. Once the risk profile is created, checks and balances to mitigate these risks can be developed". Then, the board of management needs to be a mirror for every staff who can look at and follow, or we can say "management must follow the lead of the board by acting ethically and insisting that the staff do the same". Last, "staff must also have confidence that management will fully support those who report malfeasance by others, including their superiors" (Grace \& Haupert, 2006, pp. 66-67). This is very beneficial for a corporation to know what is happening inside the company and every staff member's mind. At Google Inc., an American multinational internet and software corporation, there is a weekly open talk between the board of management and all the staffs. In these days, they drink beer together, telling jokes, share experiences and difficulties, raise questions, and ask for suggestion in a very friendly way. Thanks to the open talks and discussions like this, corporations can know what is exactly running inside their staff member's mind and be aware of what to do to keep business ethics running well.

The last in the five ways to manage business ethics effectively is advancing CSR (Porter \& Kramer, 2006). The interesting point is that:

Corporations are not responsible for all the world's problems, nor do they have the resources to solve them all. Each company can identify the particular set of societal problems that it is best equipped to help resolve and from which it can gain the greatest competitive benefit. (p. 92)

The idea is interesting because corporations are completely not social philanthropists, so they do not have to worry about all social concerns, problems, or requirements. Perceiving that doing something good for the society is also good for the companies, top management can choose only some social issues and take care of them. Focusing like this is enough, and this will help corporations have enough time and resources to deal with many other issues. For example, Aptech Limited, a leading education player with a global presence, chooses to encourage and foster education by providing computers at schools to the underprivileged and conducting training and awareness-camps. This is a very meaningful program for Aptech to show its responsibility to the community.

What is presented above shows us that there are copious ways to help improve business ethics management. Thanks to these methods, top management can have a frame of what needs to be done to take care of business ethics. However, sometimes when standing in front of many ways like this, corporations' boards of management find it hard to choose which one to follow. The followings are recommendations of some practical ways for managers to deal with managing business ethics more effectively.

\section{RECOMMENDATIONS}

First, managers have to set up an effective corporate ethics code that is written carefully and simply for every company member from top managers to staffs to understand and follow. Moreover, the corporate ethics code has to be as detailed as possible. This set of code must include all ethical business aspects of a company, so it can be considered as a concession of all matters related to business ethics between all staff members and the company.

Second, managers have to act and behave ethically in any circumstances. When managers want their employees 
to go in the same ethical way in doing business, they have to be the first ones to do that. The top managers are considered to be bright mirrors that reflect their actions to their staffs to look at. We can easily imagine what would happen if the staff members always see their managers act and behave unethically while they always ask for ethical behavior from their staffs. Apparently, these employees will perceive that it is very unfair for them to follow business ethics while their top managers do not. From this perception, the purpose of managing business ethics from top management cannot be reached.

Third, managers have to set up rules and regulations to manage business ethics in a corporation. Some people usually stick with behaving ethically, but the others may not. Therefore, the rules and regulations are set to force everybody to follow ethical actions. Anyway, when talking about rules and regulations, we are usually concerned about punishments, or penalties, to treat people when they break the rules or have unethical actions. This is a must, but not enough: if we have punishments, we also need to have awards. The awards are to encourage business people to act ethically all the time, or we can say that the awards are set to add more motivation for people to stick with business ethics.

Finally, managers have to advance CSR in a very wise way. Once again, corporations are apparently not social philanthropists. Hence, they will not have enough resources to concern themselves with every little aspect of society. Knowing the close relationship between doing something good for society and doing something good for corporations, managers have to select some, not all, social issues to work on. When they concentrate like this, they will have enough time and resources to do it well. This is beneficial for both companies and society.
These presented above are the recommendations of four ways managers should manage business ethics more effectively. Finally, there are two main issues that future researchers should take into consideration to advance business ethics. The first one is that "Do corporations need a business ethics manager or specialist?" The one in this position will have the responsibility to take care of all the issues and problems that relate to business ethics. For example, he/she will set up business ethics codes, rules and regulations, and CSR programs' plans. The second issue that future researchers should investigate is: "How do companies motivate business people to stick with acting ethically?" We did have research about penalties, but we are lacking research about awards to encourage ethical business people. It is believed that thanks to this knowledge of motivation, managers will be more confident to know how to encourage their employees to follow the corporation's business ethics.

\section{CONCLUSION}

Unlike what happened in the past, business ethics now plays a very significant role in doing business. More and more people are taking care of this matter seriously. With the purpose of discussing more about the topic, this research paper concerns about ways for managers to manage business ethics efficiently.

Beginning with the literature framework and importance of business ethics and its components such as corporate ethics code and CSR, the research stepby-step comes to the five ways to manage business ethics effectively. Additionally, knowing the importance of business ethics but not knowing how to manage it in a good manner is a hard problem for managers. The research helps to solve this by giving a set of guidelines including four recommendations: setting up an effective corporate ethics code, acting and behaving 
ethically in any circumstances, setting up rules and regulations, and advancing CSR in a very wise way.

Finally, the paper comes to give two issues for future researchers to take into consideration, in hopes that they would help. They are whether corporations need a business ethics manager or specialist and how companies motivate their employees to act ethically.

\section{REFERENCES}

1. Adler, R. (2007). Negotiating with liars. MIT Sloan Management Review, 48(4), 69-74. Retrieved from Business Source Complete database.

2. Buckhoff, T., \& E. Wilson, L. (2008). Ethical lessons for accountants. CPA Journal, 78(11), 54-56. Retrieved from Business Source Complete database.

3. Cooper, N., \& Nakabayashi, M. (2010). Serious ethical turmoil in the U.S. and Japanese life insurance markets. Journal of Financial Service Professionals, 64(2), 64-76. Retrieved from Business Source Complete database

4. DeLaurentis, T. (2009). Ethical supply chain management. China Business Review, 36(3), 38-41. Retrieved from Business Source Complete database.

5. Epstein, E. (2007). The good company: Rhetoric or reality? Corporate Social Responsibility and Business Ethics Redux. American Business Law Journal, 44(2), 207-222. doi:10.1111/j.1744-1714.2007.00035.x

6. Garone, S. J. (Ed.) (1994). Business ethics: Generating trust in the 1990s and beyond. [A conference report]. New York: The Conference Board.

7. Grace Jr., H., \& Haupert, J. (2006). How to make an ethics program work. CPA Journal, 76(4), 66-67. Retrieved from Business Source Complete database.

8. Lere, J., \& Gaumnitz, B. (2007). Changing behavior by improving codes of ethics. American Journal of Business, 22(2), 7-17. Retrieved from Business Source Complete database.

9. Mitchell, C. (2003). A short course in international business ethics: Combining ethics and profits in global business. Novaton, California: World Trade Press.

10. Pedersen, M. (2006). Business integrity in China. China Business Review, 33(1), 32-36. Retrieved from Business Source Complete database.

11. Porter, M. E., \& Kramer, M. R. (2006). Strategy \& society: The link between competitive advantage and corporate social responsibility. Harvard Business Review, 84(12): 78.

12. Prieto-Carrón, M., Lund-Thomsen, P., Chan, A., Muro, A., \& Bhushan, C. (2006). Critical perspectives on CSR and development: what we know, what we don't know, and what we need to know. International Affairs, 82(5), 977-987. doi:10.1111/ j.1468-2346.2006.00581.x 